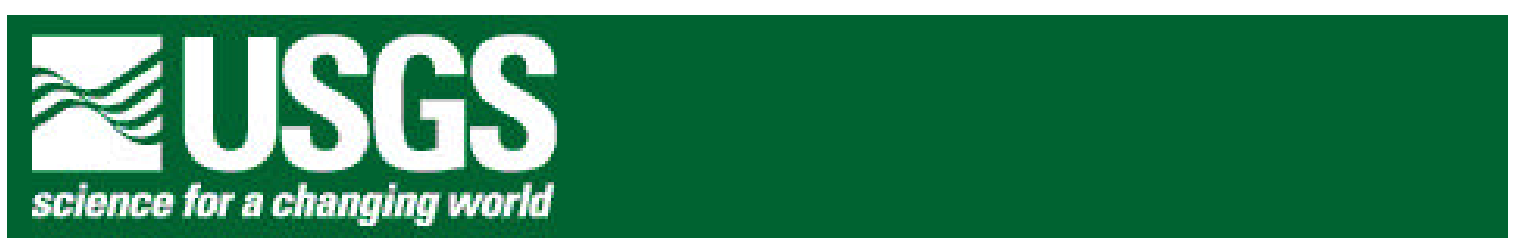

\title{
High-Resolution Seismic Reflection/Refraction Images Near the Outer Margin of the Chesapeake Bay Impact Crater, York-James Peninsula, Southeastern Virginia
}

by R. D. Catchings ${ }^{1}$, D.E. Saulter ${ }^{1}$, D. S. Powars $^{2}$, M. R. Goldman ${ }^{1}$, J. A. Dingler ${ }^{1}$, G.S. Gohn $^{2}$, J.S. Schindler ${ }^{2}$ and G. H. Johnson ${ }^{3}$

Open-File Report 01-407

2001

This report is preliminary and has not been reviewed for conformity with U. S. Geological Survey editorial standards or with the North American Stratigraphic Code. Any use of product names is for descriptive purposes only and does not imply endorsement by the U. S. Government.

\section{U.S. Geological Survey}

${ }^{1}$ U. S. Geological Survey 345 Middlefield Rd. MS 977, Menlo Park, California 94025

2 U. S. Geological Survey, 926A National Center, Reston, Virginia 20192

${ }^{3}$ College of William and Mary, Geology Department, Williamsburg, Virginia 23185 


\section{Introduction}

Powars and Bruce (1999) showed that the Chesapeake Bay region of southeastern Virginia was the site of an asteroid or comet impact during the late Eocene, approximately 35 million years ago (Fig. 1). Initial borehole and marine seismic-reflection data revealed a 90-km-diameter impact structure, referred to as the Chesapeake Bay Impact Crater (CBIC), that lies buried beneath the southern Chesapeake Bay and surrounding Virginia Coastal Plain (Powars and Bruce, Figs. 1b).

Stratigraphic correlations among a series of boreholes suggest that the impact disrupted basement rock and the overlying Cretaceous through middle Eocene deltaic and marine sediments. The CBIC truncates important regional sedimentary aquifer systems and possibly caused differential flushing of connate seawater. Therefore, the CBIC affects the present-day ground-water quantity and quality in the rapidly growing Hampton Roads region of southeastern Virginia. Impact-generated faults in the basement rock may be the sources of small-to-moderate earthquakes that have been occurred around the perimeter of the impact structure over the past few hundred years (Johnson et al., 1998).

Powars and Bruce (1999) suggest that $150 \mathrm{~m}$ to $490 \mathrm{~m}$ of relatively undisturbed, post-impact Coastal-Plain sediments overlie the impact-disrupted sediments and basement rocks west of Chesapeake Bay. Their interpretation of marine seismic data, released from Texaco and Exxon, revealed a central 38-km-wide, 1.6-km-deep disrupted zone in the basement rocks (inner basin), which is surrounded by a 21 - to 31-km-wide, 1$\mathrm{km}$-deep annular trough. Steep rim escarpments surround these features, which they mapped regionally as the outer and inner margins (rims) of the CBIC (Fig. 1b). The outer margin is a slumped terrace zone that has a 120- to 305-m-high gullied escarpment and varies in width from 0.8 to $3.2 \mathrm{~km}$. However, the geographic bounds of the CBIC, its effects on the regional aquifer systems, and the distribution of impact generated faults and fractures in basement are not well determined. To better determine some of the unknowns associated with the CBIC, we conducted a 350-m-long, high-resolution seismic reflection and refraction survey, referred to here as the CBIC-1 seismic survey, on the York-James Peninsula in June 1999. In particular, we attempted to: better define the outer margin of the CBIC, understand lateral variations in the stratigraphic sequence, help assess potential hazards associated with regional seismicity, and determine acquisition parameters needed for shallow-depth seismic imaging in the Chesapeake Bay area.

\section{Geological Framework}

The impact that produced the CBIC plunged into the shallow continental-shelf waters during the Eocene (Powars and Bruce, 1999). The impact apparently disrupted continental-margin sediments and the underlying basement rocks to a depth of at least 1.6 $\mathrm{km}$, and subsequent sedimentation covered the CBIC beneath approximately 150 to 490 $m$ of Coastal Plain deposits (Fig. 2). Coastal Plain sediments found in and around the $\mathrm{CBIC}$ can be grouped into pre-impact fluvial-deltaic and marine deposits, syn-impact (at 
the time of impact) deposits, and post-impact marine and fluvial-estuarine deposits. These units are summarized below from descriptions by Powars and Bruce (1999).

\section{Pre-Impact Units Adjacent to the Crater}

The stratigraphically lowest and chronologically oldest sediments consist of stratified fluvial-deltaic sand, silt, clay, and gravel of the Lower Cretaceous Potomac Formation. The Lower Cretaceous deposits are overlain by a sequence of marine sands and clays that include: unnamed Upper Cretaceous fluvial, deltaic, and marine deposits, the upper Paleocene Aquia Formation (4 $\mathrm{m}$ to $18 \mathrm{~m}$ of glauconite-quartz sand), the upper Paleocene and lower Eocene Marlboro Clay (2.5 m to $5.5 \mathrm{~m}$ of silty clay), the lower Eocene Nanjemoy Formation (14 m to $18 \mathrm{~m}$ of muddy sand), and the middle Eocene Piney Point Formation ( $2 \mathrm{~m}$ to $8 \mathrm{~m}$ of limestone and glauconitic quartz sand).

\section{Syn-Impact Units}

Powars and Bruce (1999) indicate that the syn-impact deposits consist of the rapidly deposited sedimentary-clast diamicton, known as the Exmore beds, and huge slump blocks composed primarily of Potomac Formation sediments, which are known as the CBIC megablock beds. The Exmore beds are $9 \mathrm{~m}$ to $33 \mathrm{~m}$ thick outside the outer margin of the CBIC and $38 \mathrm{~m}$ to $800 \mathrm{~m}$ thick inside the outer annular-trough escarpment; the megablock beds vary in thickness from $200 \mathrm{~m}$ to $760 \mathrm{~m}$.

\section{Post-Impact Units}

The post-impact units in southeastern Virginia include in ascending order: the upper-Eocene Chickahominy Formation (about $9 \mathrm{~m}$ to $27 \mathrm{~m}$ of clay outside the outer margin and $30 \mathrm{~m}$ to $106 \mathrm{~m}$ inside the margin), the lower-Oligocene Delmarva beds (about 1 $\mathrm{m}$ to $18 \mathrm{~m}$ of sand), the upper-Oligiocene Old Church Formation (less than $1 \mathrm{~m}$ to $18 \mathrm{~m}$ of silt and sand) the lower-to-middle Miocene Calvert Formation (less than $1 \mathrm{~m}$ to $168 \mathrm{~m}$ of muddy sand), the upper-Miocene St. Marys (about $9 \mathrm{~m}$ to $76 \mathrm{~m}$ of silt and clay) and Eastover Formations (11 to $64 \mathrm{~m}$ of sand), the Pliocene Yorktown Formation (up to $35 \mathrm{~m}$ of sand), the upper Pliocene Chowan River Formation (up to $15 \mathrm{~m}$ of silt and sand), the upper-Pliocene Bacons Castle Formation (silt, clay and gravel), and Quaternary deposits (up to $30 \mathrm{~m}$ of surficial sand, gravel, clay, silt, and peat).

\section{Seismic Survey}

The CBIC-1 seismic survey consisted of a 350-m-long profile that trends northwest-southeast along the axis of the lower York-James Peninsula. Seismic sources were generated by 8 -guage (400 grain) shotgun blanks fired in 0.5-m-deep boreholes, spaced approximately $5 \mathrm{~m}$ apart. Sensors consisted of 40-Hz Mark Products®, singleelement geophones, spaced $5 \mathrm{~m}$ apart and co-located with the shot points (1-m lateral separation). The geophones were connected by cable to a 60-channel, seismograph system (Geometrics Strataview RX TM). Five shot points were located beyond the ends of the geophone array (Table 1). Shot timing was determined electronically at the seismic 
source when the hammer used to trigger the Betsy Seisgun contacted the seisgun and closed the electrical circuit, sending an electrical signal to the seismograph.

Relative locations of shot points and geophones were determined using a measuring tape before the seismic data were recorded. Normally, we use high-precision GPS surveying after acquiring the data to determine distances and elevations because elevation variations can greatly affect the seismic data. However, because there were only minor variations in elevations and because the CBIC-1 profile was relatively short (350 m) and straight, we did not acquire high-precision GPS locations.

\section{Seismic Data Processing}

Because we used a shoot-through acquisition technique, whereby shots were systematically fired through the stationary recording array, both refraction and reflection data were simultaneously acquired. This acquisition method is more advantageous than conventional data acquisition methods because detailed velocity data are available, folds are typically much greater over the central part of the profile (Table 1), and shallower images are obtained. Detailed velocity data allow for better stacks in the shallow subsurface and allow depths to be correctly calculated.

Table 1. Acquisition parameters for CBIC-1 seismic profile. Distance is relative to the first shot point. CDPs $=$ common depth points.

\begin{tabular}{|l|l|l|l|l|l|l|}
\hline Profile \# & Orientation & $\begin{array}{l}\text { Geophone } \\
\text { Profile }(\mathrm{m})\end{array}$ & $\begin{array}{l}\text { Shot Point } \\
\text { Profile }(\mathrm{m})\end{array}$ & $\begin{array}{l}\text { No. of } \\
\text { shots }\end{array}$ & $\begin{array}{l}\text { No. of } \\
\text { CDPs }\end{array}$ & $\begin{array}{l}\text { Maximum } \\
\text { fold }\end{array}$ \\
\hline Profile 1 & NW - SE & 300 & 350 & 70 & 130 & 60 \\
\hline
\end{tabular}

\section{Seismic Refraction Velocity Analysis}

Seismic refraction methods measure the velocity at which seismic waves travel through the subsurface, and the velocities provide information on subsurface materials. For example, seismic waves travel faster in solid rock than in sediments, faster in clay than in sand, and faster in water-saturated sediments than in dry sediments. Using the tomographic method of Hole (1992), we modeled first-arrival refractions from about $1 \mathrm{~m}$ below the surface to about $40 \mathrm{~m}$ depth (Fig. 3). The near-surface velocity data are needed because the greatest variations in seismic velocities generally occur near the surface, where lateral variations in composition and physical state are most pronounced. Such lateral variations in velocity make it difficult to obtain a clear stack of the seismic reflection data. 


\section{Seismic Reflection Processing}

Seismic reflection data processing was accomplished on a Sun Sparc $20^{\mathrm{TM}}$ computer using an interactive seismic processing package known as ProMAX ${ }^{\mathrm{TM}}$. The following steps were involved in data processing:

Geometry Installation

Lateral distances and elevations were used to define the geometrical set up of each profile. We installed the measured shot point and geophone locations into the ProMAX ${ }^{\mathrm{TM}}$ processing package assuming no elevation variations along the profile.

Trace Editing

In places, bad coupling between the geophones and the ground, malfunctioning geophones, or cultural noise close to the seismic receivers resulted in unusually noisy traces at those locations. Traces at those locations were edited. However, such traces were not always unsuitable for each shot gather; therefore, independent trace editing was employed for each shot gather.

\section{Bandpass Filtering}

Most of the CBIC data of interest in seismic imaging are between 35 and $1200 \mathrm{~Hz}$, and most of the undesirable seismic data, such as surface waves and shear waves, were below about $35 \mathrm{~Hz}$. We used a bandpass filter with a low cut of $35 \mathrm{~Hz}$ to remove most unwanted data.

$\underline{\text { Amplitude Correction }}$

An Automatic Gain Control (AGC) of 200 ms was applied to the data.

\section{F-K Filtering}

Not all surface waves were removed by simple bandpass filtering. To remove those surface waves and airwaves that were not removed by bandpass filtering, we used an FK filter.

\section{Timing Corrections}

Although the shotgun source electronically triggers the seismographs, there are small ( $\sim 2 \mathrm{~ms})$ delays between the electrical trigger and the actual shotgun explosions. We corrected for the delays by removing a constant $2 \mathrm{~ms}$ from the start time of each shot gather.

$\underline{\text { Velocity Analysis }}$

Velocities in the shallow section ( $\sim 1 \mathrm{~m}$ to $\sim 50 \mathrm{~m}$ ) were determined using velocity inversion techniques, but velocities in the deeper section were determined assuming velocities from regional refraction profile and a nearby borehole sonic logs.

$\underline{\text { Moveout Correction }}$

Due to progressively greater travel times for the seismic waves to reach sensors that were progressively farther from each shot point, there was a delay (moveout) for each seismic arrival on the seismic record. To sum (stack) the data at each common depth point (CDP), a correction was made for the moveout using velocities obtained from the velocity analysis. 


\section{Muting}

To remove refractions and other arrivals that were not completely removed using

filtering techniques, we used trace muting before and after stacking. Stacking

To enhance the seismic signal at each location, individual reflections were summed together in a process called stacking.

\section{Depth Conversion}

For stacked seismic reflection sections that were not migrated, we converted the time sections to depth sections using RMS velocities converted from the velocity analysis described above in the velocity section.

\section{Seismic Velocity Image}

Compressional-wave velocities along the profile range from about $1300 \mathrm{~m} / \mathrm{s}$ near the surface to about $1800 \mathrm{~m} / \mathrm{s}$ at $40 \mathrm{~m}$ depth (Fig. 3). Laterally, velocities are largely uniform, varying by less than about $100 \mathrm{~m} / \mathrm{s}$ at any given depth in the upper $5 \mathrm{~m}$. From the surface to about $10 \mathrm{~m}$ below ground surface (bgs), velocities range from about 1300 $\mathrm{m} / \mathrm{s}$ to about $1500 \mathrm{~m} / \mathrm{s}$, which has been shown to correlate with the groundwater table in unconsolidated sediments in other areas (Schon, 1996; Catchings et al., 1999; Gandhok et al., 1999). If we assume the $1500 \mathrm{~m} / \mathrm{s}$ velocity as defining the water table, it probably defines the first significant water table below the seismic profile. Although shallower water tables may exist in the area, our velocity model suggests that a water table that is thick enough to propagate seismic waves is located at about $10 \mathrm{~m}$ below the ground surface along the velocity profile (Fig 3). This depth would approximately correlate with the Cornwallis-Cave aquifer described by Brockman et al. (1997).

From about $10 \mathrm{~m}$ bgs to about $40 \mathrm{~m}$ bgs, the velocity gradients are appreciably lower, varying by only about $300 \mathrm{~m} / \mathrm{s}$ over a depth range of about $30 \mathrm{~m}$. These low gradients suggest that the Coastal Plain sediments are fairly compacted from near the surface to about $40 \mathrm{~m}$ depth and do not vary much laterally. Lateral variations in the velocity contours occur principally near the ends of the seismic profile and are probably artifacts of the raytracing technique used to invert the data.

Typically, refracted first arrivals can be observed to depths that are about 25 percent of the line length in sediments. The seismic profile (actively recording geophone spread) was approximately $300 \mathrm{~m}$ in length; thus, we expected to obtain first arrival refractions from maximum depths of about $75 \mathrm{~m}$ (Fig. 3). However, our tomographic model shows that we obtained velocity information no deeper than about $40 \mathrm{~m}$. The limited depth of velocity imaging was probably caused by a lack of positive velocity gradients or negative velocity gradients at depths below about $40 \mathrm{~m}$ depth. Non-positive velocity gradients are often caused by higher-velocity material (such as clay) overlying lower velocity material (such as sand). Our seismic refraction observations are consistent with a nearby sonic log that shows seismic velocity gradients are either negative or nonpositive in the depth range from about $50 \mathrm{~m}$ to about $250 \mathrm{~m}$ (Fig. 4a). 


\section{Seismic Reflection Images}

Stacked and migrated seismic reflection images to depths of approximately $600 \mathrm{~m}$ $(\sim 1950 \mathrm{ft})$ along profile are shown in figures 4 and 5 . In both figures, we show both time (Figs. $4 \mathrm{~b}$ and 5b) and depth (Figs. 4c-e and 4c-e) sections. The depths were calculated assuming the velocity models shown in figures $4 \mathrm{a}$ and $5 \mathrm{a}$. Both velocity models are the same in the upper $50 \mathrm{~m}$, as they are derived from the tomographic model in figure 3. However, the models differ significantly for depths greater than $50 \mathrm{~m}$. The deeper $(>50$ $\mathrm{m})$ part of the velocity model of figure 4 was developed using velocities from a nearby (within $19 \mathrm{~km}$ ) borehole, and the deeper (>50 m) part of the velocity model of figure 5 was developed using velocities determined from a refraction survey in the up-dip Coastal Plain of Delaware.

The time sections show laterally continuous reflections in the upper $150 \mathrm{~ms}$ and basement reflections at about $580 \mathrm{~ms}$ (Fig $4 \mathrm{~b}$ and $5 \mathrm{~b}$ ). The time section correlates well with the marine time section in figure 6, even though the two profiles are approximately 9 $\mathrm{km}$ apart. However, the depth to these reflectors is unknown in both time sections. To calculate depth sections, we required a velocity model. Assuming the borehole velocity model (Fig. 4a), we calculate the depth to the top of the Exmore tsunami deposit to be about $175 \mathrm{~m}$ and the depth to basement at about $525 \mathrm{~m}$ (Figs. 4c-e). However, assuming the Delaware velocity model (Fig. 5a), we calculate the depth to the Exmore reflector to be about $150 \mathrm{~m}$ and the depth to basement at about $\mathbf{7 0 0} \mathrm{m}$ (Fig. 5c-e). The upper $\sim 150$ to $175 \mathrm{~m}$ (depth is velocity model dependent) of the profile have reflectors that are largely continuous along the profile. These reflectors correspond to the post-impact sediments described by Powars and Bruce (1999). Stratigraphic units underlying the post-impact sediments appear laterally discontinuous and are consistent with the expected seismic signature of the syn-impact Exmore beds and CBIC megablocks described by Powars and Bruce (1999). The disrupted (syn-impact) sediments do not image well in seismic sections, probably due to varying orientations of the units.

\section{Summary and Conclusions}

Powars and Bruce (1999) show evidence for a buried impact structure beneath the southern Chesapeake Bay and adjacent land area in Virginia. Borehole and marine seismic profiles show that the Coastal Plain sediments and underlying basement rocks in the CBIC have been disturbed by the impact. Velocities along the seismic profile do not vary appreciably in a lateral sense, and velocity gradients are relatively low. These observations of the velocity structure and data from boreholes suggest that there are multiple reversals from higher-velocity clays to lower-velocity sands in the upper $50 \mathrm{~m}$. The data also show a large reduction in the average velocity of sediments below about 50 m depth.

The CBIC has also apparently altered the ground-water system by disrupting the principal aquifers, but the upper-most aquifers (within the post-impact sediments) may 
be largely unaffected. Although there may be perched or multiple aquifers, our seismic data suggest that the shallowest major aquifer (probably the Cornwallis-Cave aquifer) is probably located at about $10 \mathrm{~m}$ depth, based on the depth to sediments with velocities of $\sim 1500 \mathrm{~m} / \mathrm{s}$.

Seismic time sections from marine profiles and those from our land-based profile show the same travel times to basement, but the depth sections are highly dependent on the velocity model, with depths to basement varying by about $130 \mathrm{~m}$ ( about $525 \mathrm{~m}$ versus $700 \mathrm{~m}$ ). The depth to shallower Exmore-bed reflectors varies less, differing by about $25 \mathrm{~m}$ in the two models (150 m versus $175 \mathrm{~m}$ ).

Our profile was designed to look for the disruptions in sediments that may correspond to the outer rim of the CBIC. We did not image a specific outer rim because the profile was too short in length and was located too far east. However, when projected northward onto the marine seismic profile, our profile imaged similar reflectors with comparable dips (Fig. 7). The correlation of reflectors suggests that our profile imaged only a small part of the outer rim and was slightly east of the highest part of the outer rim (Fig. 7). Our profile also shows that sediments below the Chickahominy Formation (oldest post-impact unit) and above basement are probably disrupted, as most reflectors in that depth range do not extend across the length of the profile. The depth to the disrupted sediments is velocity-model dependent. Using the borehole model, the depth to the disrupted reflectors is calculated to be about $175 \mathrm{~m}$, whereas the depth to the disrupted reflectors is calculated to be about $150 \mathrm{~m}$ using the Delaware velocity model.

Seismic energy generated by the Betsy Seisgun source propagated well through the Coastal Plain sediments, suggesting that the seisgun should be sufficient for future surveys seeking to image to basement. The data also show that relatively high frequencies (up to hundreds of $\mathrm{Hz}$ ) can be recovered from the Coastal Plain sediments (Fig. 4e and 5e), and these high frequencies show more detail with respect to the shallow structure. Because of the velocity reversals in the upper 50 to $60 \mathrm{~m}$, the data suggest that very long spreads or offsets (perhaps kilometers) are required to obtain refracted velocities for strata below $50 \mathrm{~m}$ depth.

\section{Data Availability}

Data from this seismic survey are available by contacting R. D. Catchings at the address listed on the cover of this report.

\section{Acknowledgments}

We thank Andy Gallardo for field assistance in acquiring the seismic data. The project was funded in part by the Hampton Roads Planning District Commission and the U.S. Geological Survey. 


\section{References}

Brockman, A.R., D.L. Nelms, G.E Harlow, Jr., and J.J. Gildea, 1997, Geohydrology of the shallow aquifer system, Naval Weapons Station, Yorktown, Virginia: U.S. Geological Survey Water-Resources Investigations Report 97-4188, 61 p.

Catchings, R. D., E. Horta, M.R. Goldman, M.J. Rymer, and T.R. Burdette, 1998, High-resolution seismic imaging for environmental and earthquake hazards assessment at the Raychem Site, Menlo Park, California, U.S. Geol. Surv. OpenFile Report 98-146, 37 pp.

Catchings, R.D., G. Gandhok, M.R. Goldman, E. Horta, and M.J. Rymer, P. Martin, A. Christensen, 1999, High-resolution seismic reflection/refraction imaging beneath Cherry Valley, Riverside County, California: Implications for water resources and earthquake hazards, U.S. Geol. Surv. Open-File Report 99-26, 58 pp.

Gandhok, G., R. D. Catchings, M. R. Goldman, E. Horta, M. J. Rymer, P. Martin, and A. Christensen, 1999, High-resolution seismic reflection/refraction imaging from Interstate 10 to Cherry Valley Boulevard, Cherry Valley, Riverside County, California: Implications for water resources and Earthquake Hazards, U.S. Geological Survey Open-file Report 99-320, 52 pp.

Hole, J.A, 1992, Nonlinear high-resolution three-dimensional seismic travel time tomography, J. Geophys. Res., v. 97, p. 6553-6562.

Johnson, G.H., S. E. Kruse, A.W.. Vaughn, J.K. Lucey, C.H. Hobbs, and D. S. Powars, 1998, Geology, v.26, p. 507-510

Powars, D.S. and T.S Bruce 1999, The Effects of the Chesapeake Bay Impact Crater on the Geologic Framework and Correlation of Hydrogeologic Units of the Lower York-James Peninsula, Virginia, US Geological Survey Professional Paper 1612.

Schon, J. H., 1996, Physical Properties of Rocks: Fundamentals and Principals of Petrophysics, Handbook of Geophysical Exploration, Seismic Exploration vol. 18, Elsevier Science, Inc., Tarrytown, New York 


\section{Figures}

Figure 1 (a) Location of the Mid-Atlantic region of the United States. The box shows the approximate area of figure 1b. (b) Approximate location of the inner and outer margins of the Chesapeake Bay Impact Crater. The box shows the approximate location of figure 1c. Map showing the approximate location of a marine seismic profile (CC') along the York River and the locations of boreholes shown from Fig. 2. (c) Photo of Newport News, Virginia area with the location of the CBIC1 seismic profile from this study and wells 65 and 66.

Figure 2. Fig. 2 Interpretative cross section across a southwestern portion of the Chesapeake Bay impact crater (from Powars and Bruce, 1999). The cross section is based on borehole and seismic data. The approximate location of the $\mathrm{C}-\mathrm{C}^{\prime}$ marine seismic survey is shown in yellow above the cross section, and the approximate location of the CBIC-1 seismic profile from this study is shown in red.

Figure 3. Tomographic velocity model along the CBIC-1 profile, derived from inversion of first-arrival refractions.

Figure 4a. Velocity model derived from a velocity inversion of the land-based seismic refraction data of this study (upper $50 \mathrm{~m}$ ) and sonic logs from a borehole located about $19 \mathrm{~km}$ to the southeast (lower $500 \mathrm{~m}$ ). (b) Seismic reflection time section for the CBIC-1 land-based seismic profile with a low-cut minimum bandpass of $40 \mathrm{~Hz}$. (c) Seismic reflection depth section for the CBIC-1 profile with a minimum bandpass of $40 \mathrm{~Hz}$ and stacked with the velocity model shown in figure 4a. (d) Same seismic section as shown in figure 4c, but the minimum bandpass is $75 \mathrm{~Hz}$. (e) Same seismic depth section as in figure 4c, but the minimum bandpass is $150 \mathrm{~Hz}$. Basement is located at about $525 \mathrm{~m}$ depth on the basis of the velocity model used in figure $4 \mathrm{a}$. Reflectors below about $350 \mathrm{~m}$ depth are laterally less continuous.

Figure 5. Velocity model derived from a velocity inversion of the land-based seismic refraction data of this study (upper $50 \mathrm{~m}$ ) and a velocity model from refraction data from the Delaware Coastal Plain (lower $500 \mathrm{~m}$ ). (b) Seismic reflection time section for the CBIC-1 land-based seismic profile with a low-cut minimum bandpass of $40 \mathrm{~Hz}$. (c) Seismic reflection depth section for the CBIC-1 profile with a minimum bandpass of $40 \mathrm{~Hz}$ and stacked with the velocity model shown in figure 5a. (d) Same seismic section as shown in figure 5c, but the minimum bandpass is $75 \mathrm{~Hz}$. (e) Same seismic depth section as in figure 5c, but the minimum bandpass is $150 \mathrm{~Hz}$. Basement is located at about $680 \mathrm{~m}$ depth on the 
basis of the velocity model used in figure 5a. Reflectors below about $150 \mathrm{~m}$ depth are laterally less continuous.

Figure 6. Marine seismic reflection time section along the York River (from Powars and Bruce, 1999). This profile was located about $9 \mathrm{~km}$ northward of the land-based CBIC-1 seismic profile. The arrow shows the approximate outer rim of the impact crater. The strong reflectors at about $0.55 \mathrm{sec}$ are probably crystalline basement reflectors.

Figure 7 Seismic profiles from figure 6, with the CBIC-1 profile superimposed at its northward projection onto the marine seismic profile. Note that there are similar reflectors at similar depths on both profiles. 
Fig. 1a Location of the Mid-Atlantic region of the United States. The box shows the approximate area of figure $1 \mathrm{~b}$.

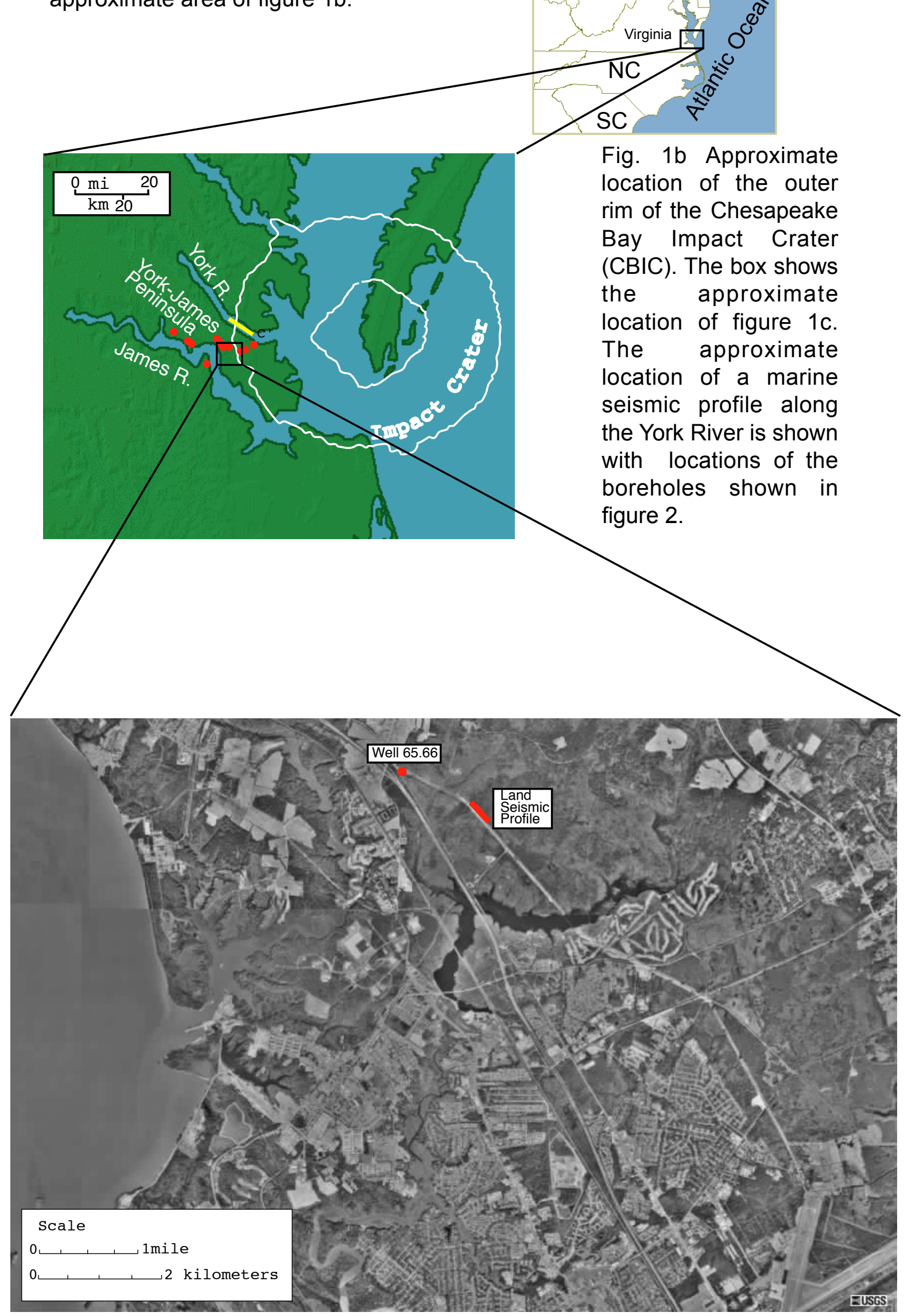

Fig. 1c Photo of Newport News, Virginia area with the locations of the seismic profile from this study and boreholes 65 and 66 shown on figure 2 . 


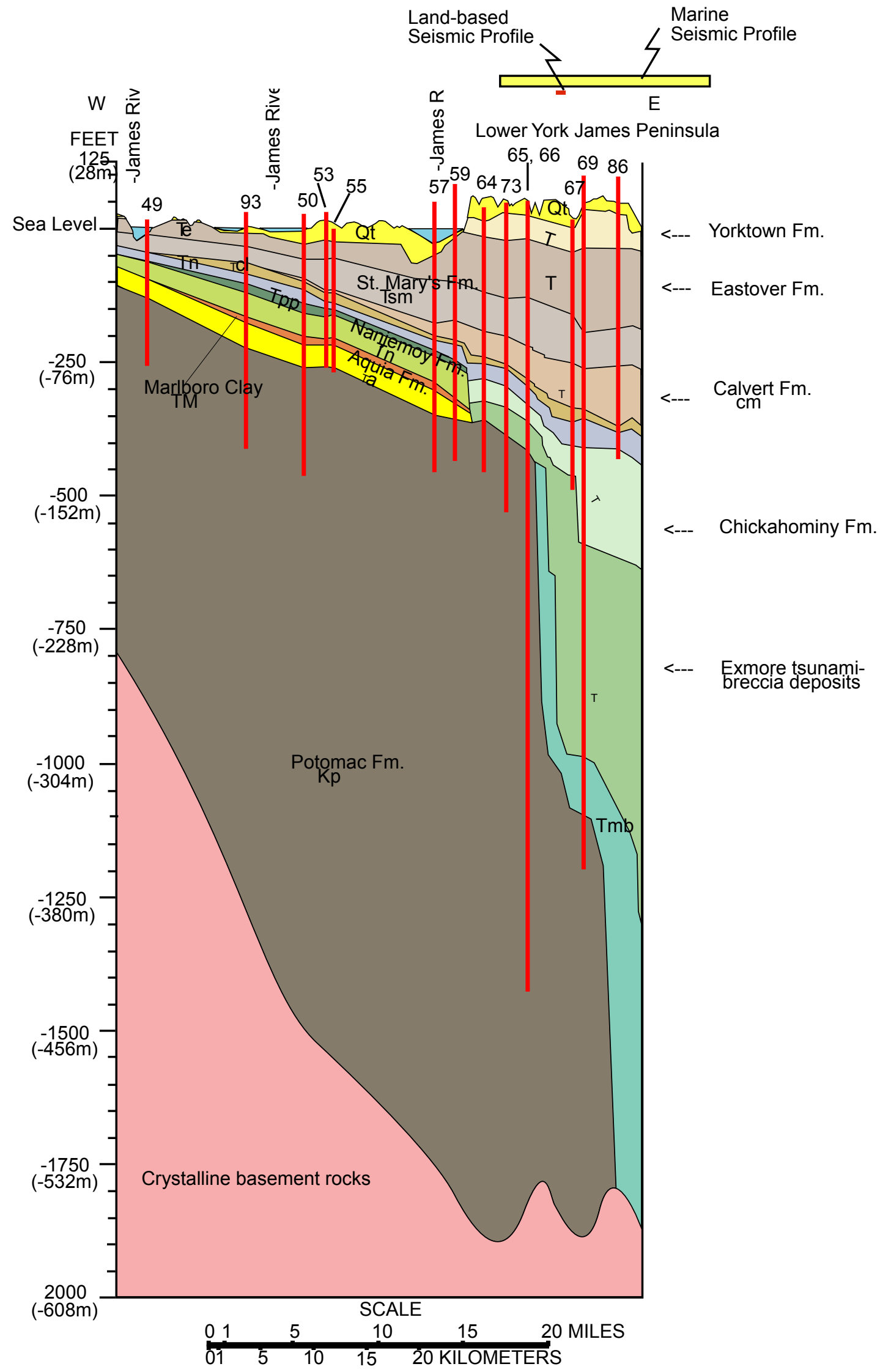

Fig. 2 Interpretative cross section across the Chesapeake Bay impact crater (from Powers and Bruce, 1999). The cross section is based on borehole and seismic data. The approximate locations of the C-C' marine and the CBIC-1 seismic surveys are shown in yellow and red, repectively, above the cross section. 


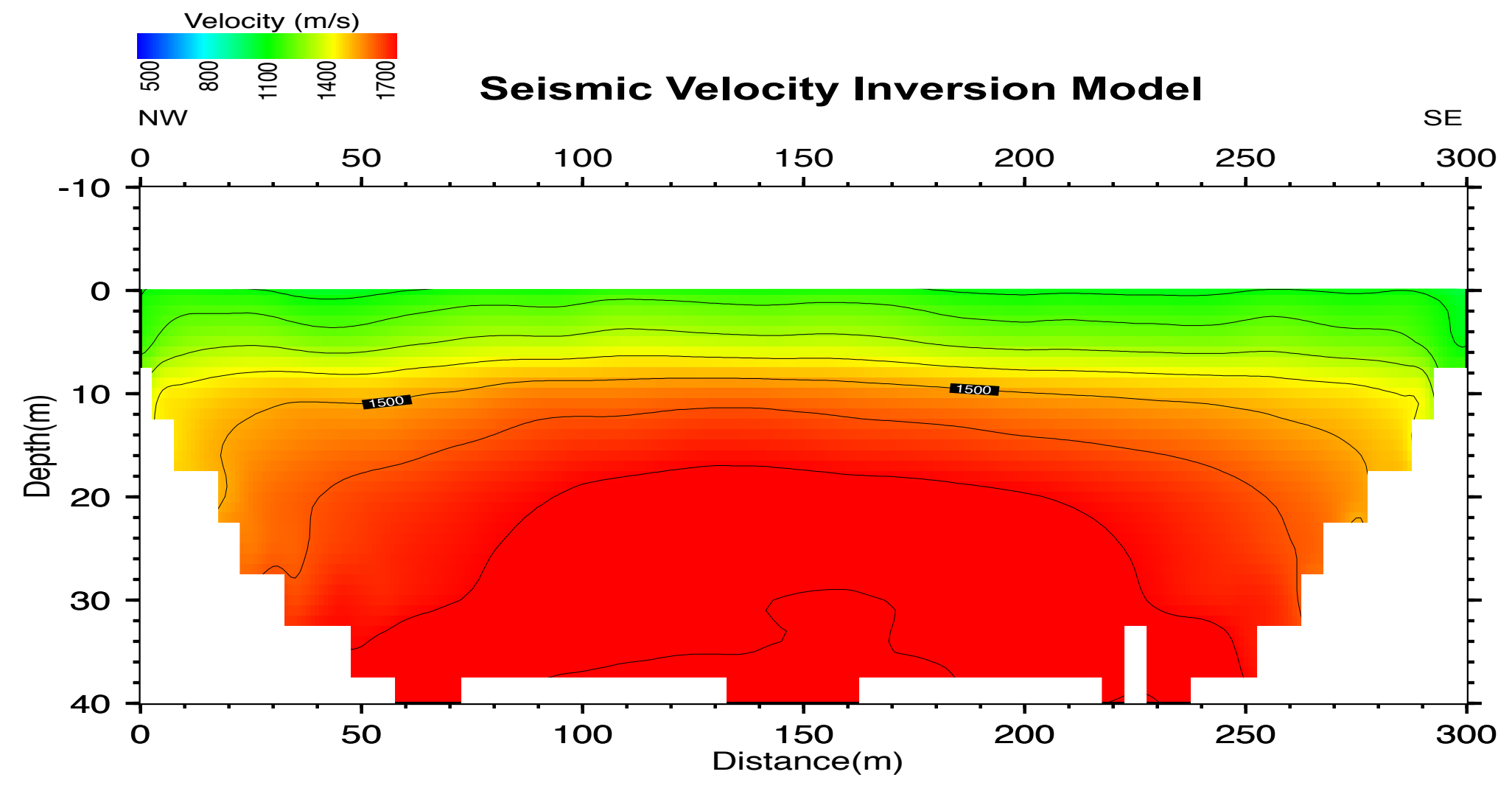

Fig. 3 Tomographic velocity model along the CBIC I profile, derived from inversion of first-arrival refractions 


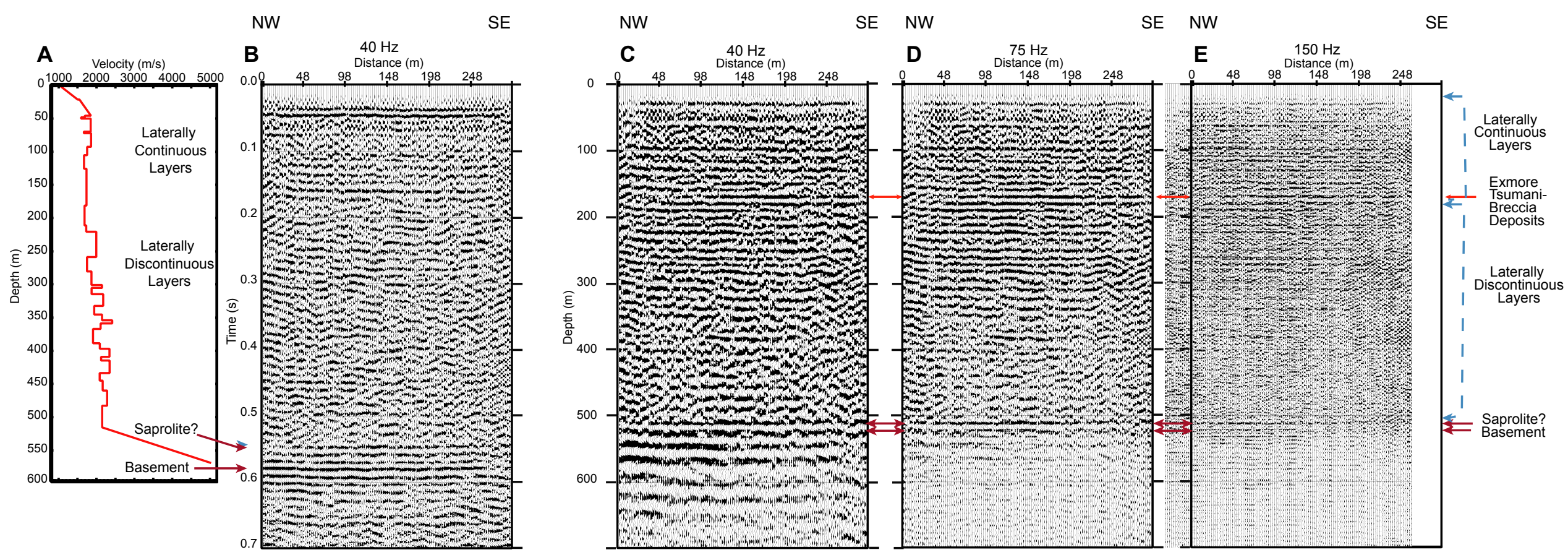

Fig. 4a Velocity model derived from a velocity inversion of the land-based seismic refraction data of this study (upper $50 \mathrm{~m}$ ) and sonic logs from a borehole located about $19 \mathrm{~km}$ to the southeast (lower $500 \mathrm{~m}$ ). (b) Seismic reflection time section for the CBICS-1 land-based seismic profile with a low-cut minimum bandpass of $40 \mathrm{~Hz}$. (c) Seismic reflection depth section for the CBICS-1 profile with a minimum bandpass of $40 \mathrm{~Hz}$ and stacked with the velocity model shown in figure 4a. (d) Same seismic section as shown in figure 4c, but the minimum bandpass is $75 \mathrm{~Hz}$. (e) Same seismic depth section as in figure 4c, but the minimum bandpass is $150 \mathrm{~Hz}$. Basement is located at about $525 \mathrm{~m}$ depth on the basis of the velocity model used in figure 4a. Reflectors below about $175 \mathrm{~m}$ depth are less laterally continuous. 
NW

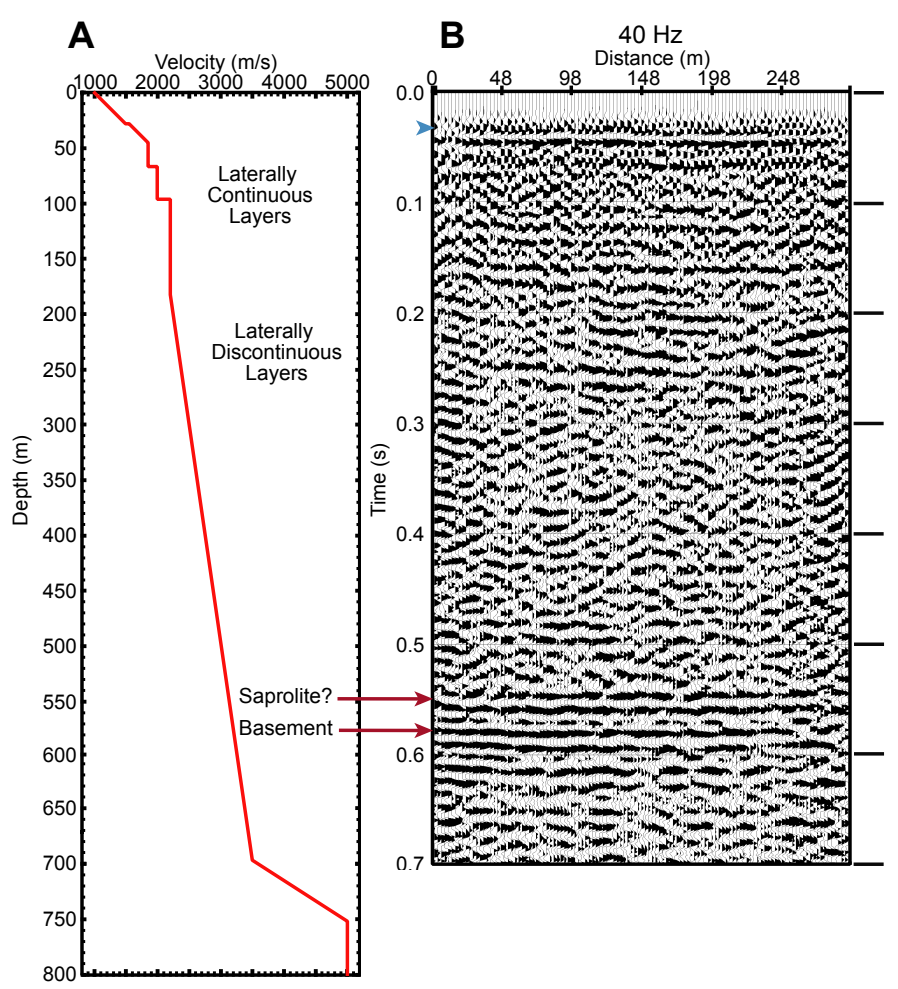

NW

SE

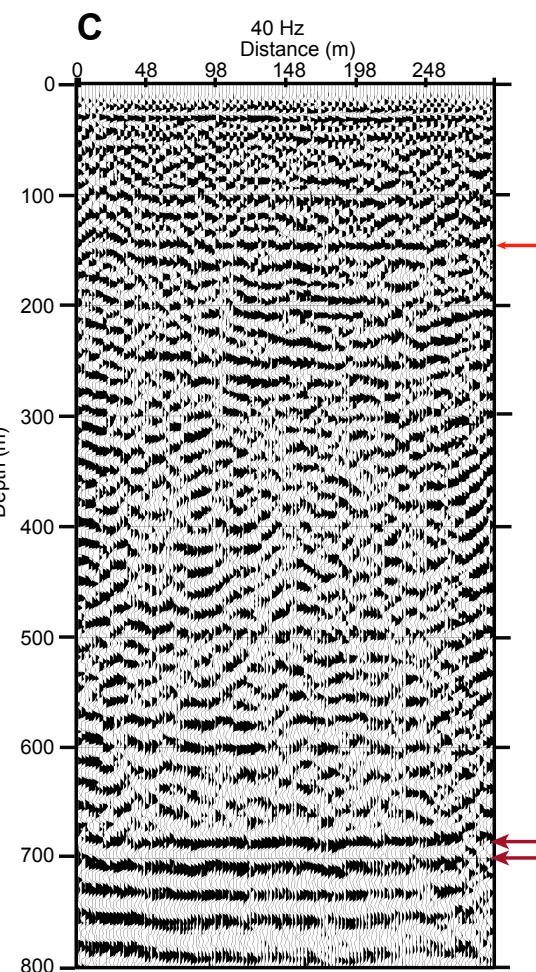

NW

SE

NW

SE

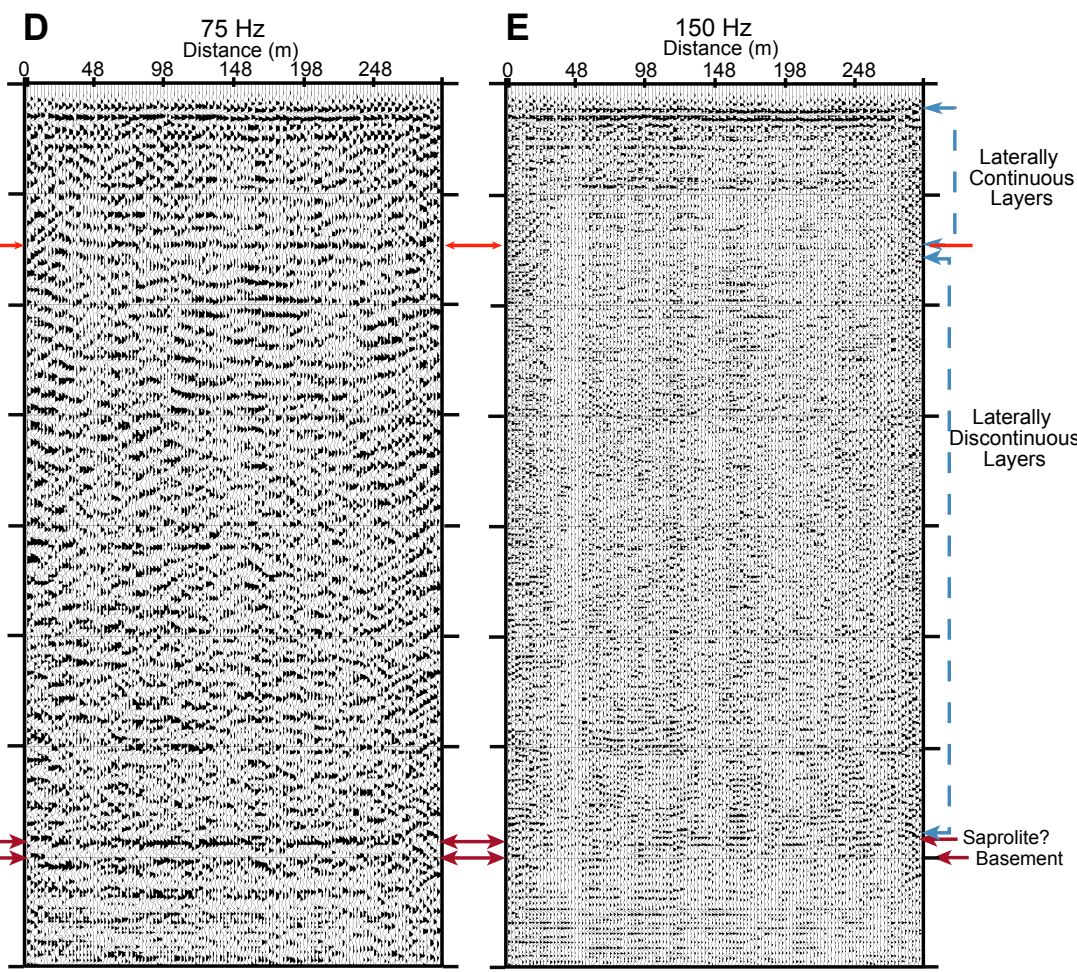

Fig. 5 (a) Velocity model derived from the land-based seismic refraction data of this study (upper $50 \mathrm{~m}$ ) and a velocity model from refraction data from the Delaware Coastal Plain (lower $500 \mathrm{~m}$ ). (b) Seismic reflection time section for the CBICS-1 land-based seismic profile with a low-cut minimum bandpass of $40 \mathrm{~Hz}$. (c) Seismic reflection depth section for the CBICS-1 profile with a minimum bandpass of $40 \mathrm{~Hz}$ and stacked with the velocity model shown in figure 5a. (d) Same seismic section as shown in figure $5 \mathrm{c}$, but the minimum bandpass is $75 \mathrm{~Hz}$. (e) Same seismic depth section as in figure $5 \mathrm{c}$, but the minimum bandpass is $150 \mathrm{~Hz}$. Basement is located at about $680 \mathrm{~m}$ depth on the basis of the velocity model used in figure 5a. Reflectors below about $150 \mathrm{~m}$ depth are less laterally continuous. 


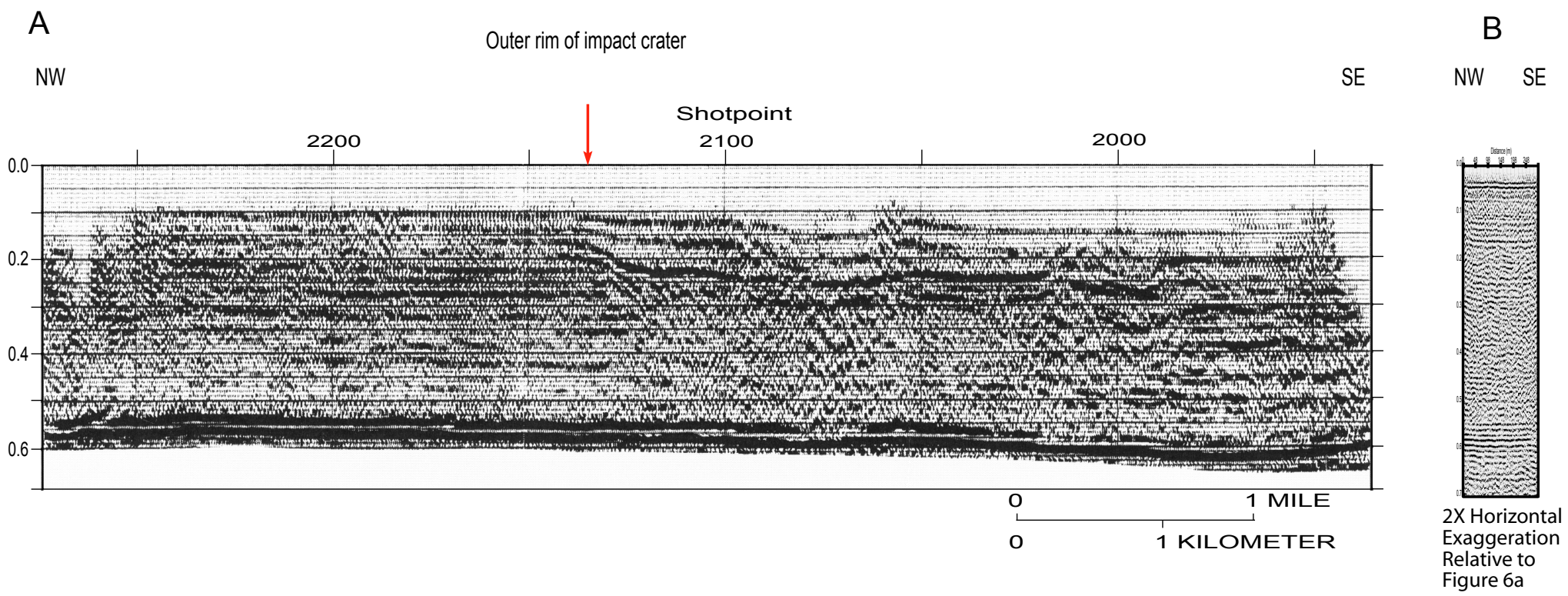

Fig. 6 (a) Marine seismic reflection time section along the York River (from Powars and Bruce, 1999) and (b) the seismic CBIC1 reflection time section from this study. This marine profile was located about than $9 \mathrm{~km}$ northward from the CBIC-1 landbased seismic profile (see Fig. 1b). The red line marks the approximate outer margin of the impact crater. The strong reflectors at about $0.55 \mathrm{sec}$ are probably crystalline basement reflectors. 


\section{Outer im of impact crater}

NW

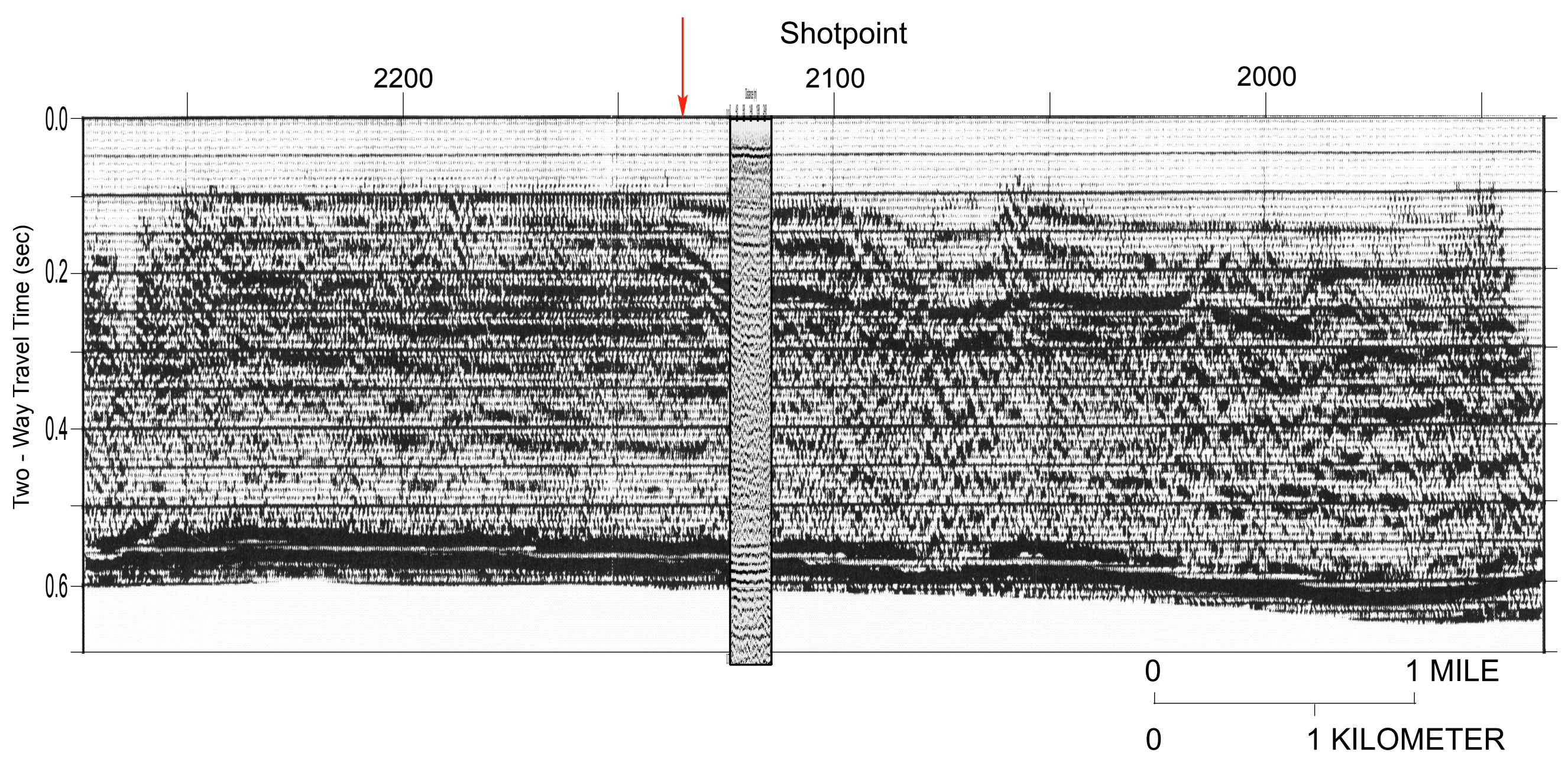

Fig. 7 Seismic profiles from figure 6, with the CBICS 1 profile superimposed at its northward projection onto the marine seismic profile. Both profiles are at the time and distance scales. 